\title{
Laboratory study of heterogeneous ice nucleation in deposition mode of montmorillonite mineral dust particles aged with ammonia, sulfur dioxide, and ozone at polluted atmospheric concentrations
}

\author{
Abdus Salam • Glen Lesins • Ulrike Lohmann \\ Received: 7 September 2008 / Accepted: 22 October 2008 / Published online: 13 November 2008 \\ (C) The Author(s) 2008. This article is published with open access at Springerlink.com
}

\begin{abstract}
Heterogeneous ice nucleation in deposition mode of montmorillonite mineral dust aerosol particles exposed to atmospheric trace gases (ammonia, sulfur dioxide, and ozone) was studied at temperatures warmer than $-40^{\circ} \mathrm{C}$ with a continuous flow diffusion chamber. Pure and typical polluted atmospheric concentrations of ammonia, sulfur dioxide, and ozone gases were used to age montmorillonite mineral dust aerosol particles at room temperature and atmospheric pressure in a stainless steel chamber. Ammonia-, sulfur dioxide-, and ozone-exposed montmorillonite mineral dust aerosols act as ice nuclei in heterogeneous deposition freezing at warmer temperatures than required for homogeneous freezing. The ice nucleation efficiency of montmorillonite mineral dust aerosols increased about two times due to exposure to ammonia at a typical atmospheric concentration of about $100 \mathrm{ppt}$. This is the first experimental evidence for the enhancement of the ice nucleation efficiency of montmorillonite mineral dust aerosols by ammonia gas at typical atmospheric concentrations. Montmorillonite exposure to either pure (100\%) or $45 \mathrm{ppm}$ sulfur dioxide or to ozone at $200 \mathrm{ppb}$ shows no clear evidence for changing the ice nucleation efficiency of montmorillonite mineral dust par-
\end{abstract}

\footnotetext{
A. Salam $(\bowtie)$

Department of Chemistry, University of Dhaka,

Dhaka 1000, Bangladesh

e-mail: asalam@gmail.com

G. Lesins

Department of Physics and Atmospheric Science,

Dalhousie University,

Halifax, Canada

U. Lohmann

Institute of Atmospheric and Climate Science,

ETH Zurich, Switzerland
}

ticles. Thus, we conclude that enhancements atmospheric trace gases (e.g., sulfur dioxide and ozone) due to anthropogenic activities have no significant impact on the heterogeneous ice nucleation of montmorillonite mineral dust particles.

Keywords Deposition freezing · Ice nucleation . Montmorillonite $\cdot$ Sulfur dioxide $\cdot$ Ozone $\cdot$ Ammonia

\section{Introduction}

Atmospheric dust aerosol particles have a direct impact on climate forcing by modifying the radiation balance and affecting cloud nucleation and cloud optical properties (Forster et al. 2007; McConnell et al. 2007). Changes in cloud optical properties and cloud lifetime are the key elements contributing to the indirect aerosol radiative effect (Lohmann and Feichter 2005). Cloud radiative properties can be modified when aerosol dust particles act as cloud condensation nuclei or ice nuclei (Twomey 1974; Pruppacher and Klett 1997; Ramanathan et al. 2001). The activity of ice nuclei is important for the rate at which supercooled clouds will glaciate, the ability of clouds with moderate to weak supercooling and updrafts to precipitate, and for the lifetime of supercooled clouds. The possibility that atmospheric trace gases can modify the activity of ice nuclei means that anthropogenic emissions of gases may indirectly impact cloud properties through the ice nucleation pathway.

Four ice nucleation mechanisms are already recognized (Vali 1985; Rogers and Yau 1989). The first of these is deposition nucleation in which a direct transition from vapor to solid (ice) occurs on a foreign particle (ice nucleus) in an environment supersaturated with respect to ice without the intermediate liquid phase formation. The second mechanism is condensation freezing nucleation, 
which initially requires condensation of liquid water from the vapor onto an ice nucleus surface. The liquid then freezes to form an ice crystal. The third process is immersion freezing in which ice nuclei embedded in a droplet initiate freezing to form an ice crystal. The fourth mechanism is contact freezing in which ice nuclei promote freezing instantly when they come in contact with a supercooled droplet. The focus of this work is on the heterogeneous ice nucleation in deposition mode on mineral dust aerosol particles.

Mineral dust particles are one of the most abundant aerosols by mass in the atmosphere (Andreae et al. 1986; Penner and Lagaly 2001). Mineral dust aerosols are thought to play an important role as ice nuclei in mixed phase and ice clouds in the atmosphere (Zuberi et al. 2002; DeMott et al. 2003). Evidence of Asian desert dust particles acting as effective ice nuclei at temperatures warmer than that required for homogeneous freezing was obtained from continuous flow diffusion chamber data (DeMott et al. 2003). Different field and laboratory studies have shown that mineral dust aerosol particles act as effective ice nuclei in either deposition or condensation nucleation modes (Kumai 1961; Kumai and Francis 1962; DeMott et al. 2003; Sassen et al. 2003; Sassen 2005; Archuleta et al. 2005; Diehl et al. 2006; Field et al. 2006; Kanji and Abbatt 2006; Knopf and Koop 2006; Möhler et al. 2006; Salam et al. 2006). Archuleta et al. (2005) reported pure metal oxide and sulfuric-acid-coated metal oxide particles activated by heterogeneous ice nucleation at lower relative humidities than those required for homogeneously freezing of sulfuric acid solution particles with a continuous-flow ice thermal diffusion chamber. Knopf and Koop (2006) found that uncoated and sulfuric-acid-coated Arizona test dust particles nucleate ice at considerably lower relative humidities than required for homogeneous ice nucleation between the temperatures of $-70^{\circ} \mathrm{C}$ and $-13^{\circ} \mathrm{C}$. No significant difference was observed in the ice nucleation ability of uncoated and sulfuric-acid-coated Arizona test dust particles (Knopf and Koop 2006). From the table in Diehl et al. (2006), it can be seen that the warmest median freezing temperature in the contact mode was found for bacteria, followed by montmorillonite, leaf litter, pollen, kaolinite, and finally by soot particles. In the immersion mode, all biological particles showed higher median freezing temperatures than the mineral dust particles and soot. Montmorillonite can also act as an efficient ice nucleus in immersion mode, causing aqueous $\left(\mathrm{NH}_{4}\right)_{2} \mathrm{SO}_{4}-\mathrm{H}_{2} \mathrm{O}$ particles to freeze at warmer temperatures (Zuberi et al. 2002).

The atmospheric trace gases (ammonia, sulfur dioxide, and ozone) used in this study are produced mainly by anthropogenic activities. Mineral dust is recognized as a potential sink for some atmospheric trace gases such as ammonia (Russell 1965) and sulfur dioxide (Ullerstam et al.
2003; Usher et al. 2003). In earlier studies, Birstein (1957, 1960) investigated the chemisorption of trace gases on the surface of silver iodide and lead iodide and, subsequently, their impact on ice formation in a super-cooled cloud at $-20^{\circ} \mathrm{C}$. They found that the presence of ammonia gas decreased the ice nucleation ability of silver iodide particles. The interactions of the trace gases with mineral dust particles have been studied (Russell 1965; Ogloza and Malhotra 1989; Umann et al. 2005). However, the potential impact of trace gases on ice nucleation is still not well understood.

In this study, we report the results of the ice nucleation characteristics of montmorillonite mineral dust aerosols that have been exposed to the atmospheric trace gases ammonia, sulfur dioxide, and ozone at temperatures between $-10^{\circ} \mathrm{C}$ and $-40^{\circ} \mathrm{C}$ at different saturation conditions with the continuous flow diffusion chamber (CFDC) at Dalhousie University, Canada. Typical polluted urban atmospheric concentrations of the three trace gases were used in the ageing of the montmorillonite mineral dust aerosol particles for the ice nucleation study. This represents an improvement over Salam et al. (2007) where the levels of ammonia used were larger than found in the atmosphere. Also new in this study is the aging of montmorillonite with sulfur dioxide and ozone and their ice nucleation characteristics.

\section{Experimental description}

\section{Ozone generation}

A commercially available ozone generator (Ozone Services, Yanco Industries Ltd., Model OL80, Canada) was used for ozone production. Ozone is produced from oxygen gas where the oxygen flow rate can vary between 0 and $1,000 \mathrm{~mL} \mathrm{~min}^{-1}$. The production efficiency of this instrument is up to $12.5 \%$ (by weight). An oxygen gas cylinder (Prax Air Ltd., Canada) was connected to the input of the ozone generator, while the output of the ozone generator was blended with nitrogen gas (Prax Air Ltd.) through two sets of flow meters (Advanced Specialty Gas Equipment, Part Number 463114) to dilute the ozone gas to as low as a few parts per trillion (ppt). The diluted ozone gas was then allowed to interact with the montmorillonite mineral dust particles in the aging chamber as described below.

Trace gas exposure to mineral dust particles

Montmorillonite mineral dust particles were aged with the atmospheric trace gases in a stainless steel cylindrical chamber ( $45 \mathrm{~cm}$ long with a diameter of $20 \mathrm{~cm}$ ). About $5 \mathrm{~g}$ of montmorillonite K10 (Sigma-Aldrich, Powder) mineral 
dust particles was placed on the bottom of the cylindrical chamber for each aging session. Ammonia (100\% pure and $100 \mathrm{ppt}$ in $\mathrm{N}_{2}$ gas medium), sulfur dioxide (100\% pure and $45 \mathrm{ppm}$ in $\mathrm{N}_{2}$ gas medium), and ozone from the ozone generator $(200 \mathrm{ppb})$ were allowed to pass into the chamber with occasional stirring so that the gas exposure would be uniform on the montmorillonite dust surface. Montmorillonite particles were exposed about $2.5 \mathrm{~h}$ with $100 \%$ pure ammonia and $100 \%$ pure sulfur dioxide and $70 \mathrm{~h}$ with $100 \mathrm{ppt}$ ammonia, $45 \mathrm{ppm}$ sulfur dioxide, and $200 \mathrm{ppb}$ ozone gas. The diluted concentrations of ammonia, sulfur dioxide, and ozone are typical of highly polluted urban environments (Godish 2003).

Generation of aerosol particles and impaction

Unexposed montmorillonite and ammonia-, sulfur dioxide-, and ozone-gases-exposed montmorillonite mineral dust particles were placed into the CFDC aerosol generator. The details of the aerosol generator and also the impaction system were described previously (Salam et al. 2006). Briefly, the generator is an airtight reservoir with a vibrating Mylar membrane at its base held in place with an aluminum collar and an o-ring seal and is vibrated using a square wave generator at $1,000 \mathrm{~Hz}$. The aerosol particles levitated by the generator were introduced to the flow entering the diffusion chamber. Before entering the cham- ber, the aerosol particles passed through an inertial impactor (Marple and Willeke 1976; Salam et al. 2006) to remove particles larger than $5.0 \mu \mathrm{m}$, allowing only montmorillonite mineral dust particles smaller than $5.0 \mu \mathrm{m}$ to enter the CFDC.

\section{Description of the CFDC system}

The CFDC (Salam et al. 2006) was used to carry out the ice nucleation experiments. Figure 1 shows a detailed schematic diagram of the CFDC system. The CFDC is a vertically oriented flow chamber consisting of two concentric circular copper cylinders. The length of the chamber is $161 \mathrm{~cm}$, the top $123 \mathrm{~cm}$ is cooled, while the bottom $38 \mathrm{~cm}$ has no active cooling. The region without cooling is kept at ice saturation. It is needed to evaporate any water droplets that might have potentially formed and could be misinterpreted as ice crystals by the particle counter at the exit of the CFDC. The annular gap between the two cylinders, in which the ice crystals grow, is $0.45 \mathrm{~cm}$, and this results in a Reynolds number of about 20, indicative of laminar flow in the annulus gap. Prior to each experiment, the annulus gap of the chamber was flooded with water for about $2 \mathrm{~s}$ in order to freeze a thin film of ice on the inside walls. During the experiment, the two walls are held at two different temperatures at ice saturation to allow the diffusion of heat and water vapor to create a steady-state supersaturation

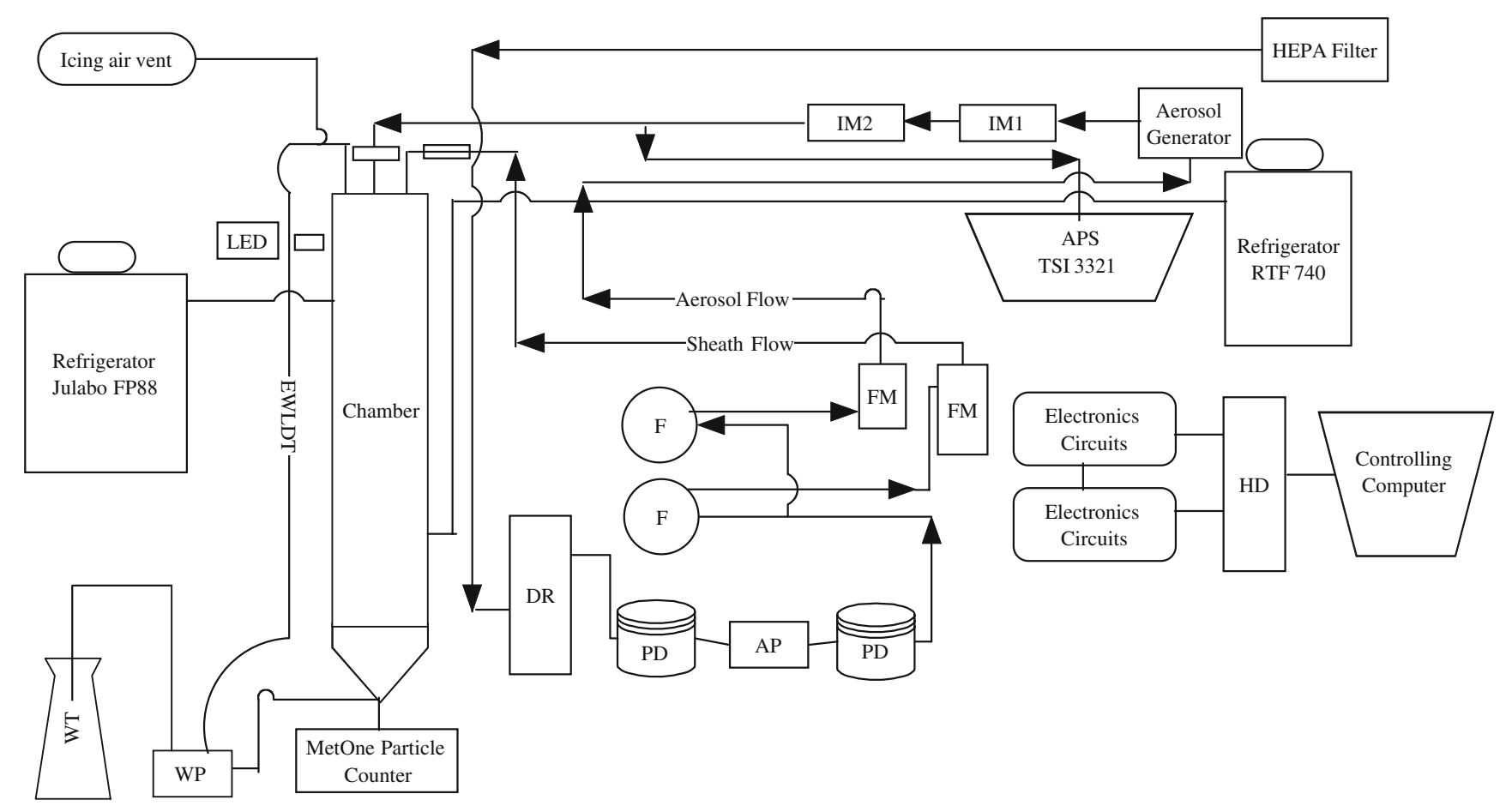

Fig. 1 Schematic diagram of the continuous flow diffusion chamber $(C F D C)$ at Dalhousie University, Canada. Arrows indicate the airflow in the CFDC system. EWLDT external water level detection tube, WT water tank, $W P$ water pump, $D R$ drierite holder, $F$ inline filter, $F M$ flow meter, $P D$ pulse dampeners, $A P$ air pump, $I M$ impactor, $H D$ computer hard disk 
with respect to ice near the center of the annulus gap through which the aerosols are carried and, if activated, will grow by water vapor deposition to ice crystals. The air stream containing the aerosols is surrounded by two clean sheath air streams which confine all the aerosols to the center of the annulus gap where the ice supersaturation conditions exist. Typical operating conditions of the chamber are temperatures between $-2^{\circ} \mathrm{C}$ and $-45^{\circ} \mathrm{C}$, temperature differences between two walls from $0^{\circ} \mathrm{C}$ $\left(273^{\circ} \mathrm{K}\right)$ to $20^{\circ} \mathrm{C}\left(293^{\circ} \mathrm{K}\right)$, supersaturation with respect to water ( $\mathrm{SSw})-30 \%$ to $+10 \%$; supersaturation with respect to ice $0 \%$ to $+50 \%$, total air flow $2.83 \mathrm{~L} \mathrm{~min}^{-1}$, and residence time for the aerosol particles in the actively cooled portion of the chamber of $20 \mathrm{~s}$. Further details of the CFDC can be found in Salam et al. (2006).

\section{Determination of ice crystals}

The ice crystal particles were detected with a MetOne (Model 278B) optical particle counter at the outlet of the CFDC (Salam et al. 2006, 2007). Aerosol particles smaller than $5.0 \mu \mathrm{m}$ in diameter produced by the aerosol generator were injected into the center of the gap near the location of the maximum supersaturation. Ice crystals were activated and grew in the chamber while being carried by the air stream and were identified with the MetOne (model 278B) optical particle counter. The flow rate of the MetOne particle counter is $2.83 \mathrm{~L} \mathrm{~min}^{-1}$, which is the same as the chamber flow (sum of the aerosol and the two sheath flows). The MetOne particle counter can measure particles with sizes from 0.3 to $20 \mu \mathrm{m}$ using six size bins $(0.3,0.5$, $0.7,1.0,2.0$, and $5.0 \mu \mathrm{m}$ size bin). In this study, we used only the size bin greater than $5.0 \mu \mathrm{m}$ for the ice crystal number concentration measurements, which range from 5.0 to $20 \mu \mathrm{m}$. An aerodynamic particle sizer (APS), TSI 3321 (Peters and Leith 2003), was used to verify the accuracy of MetOne particle counter (model 278B). Unfortunately the APS could not be used for detection of the ice crystals at the bottom of the CFDC. The total number concentrations of montmorillonite mineral dust particles were measured with both the MetOne and APS, and they agreed within $5 \%$ of each other for the same size bin. Since the impactor at the input to the CFDC removes aerosol particles larger than $5.0 \mu \mathrm{m}$, we can assume, after performing the quality controls described in the next subsection, that particles greater than $5.0 \mu \mathrm{m}$ detected by the MetOne are ice crystals. The detected ice nuclei fraction $\left(\mathrm{IC}_{>5} / \mathrm{APS}_{<5}\right)$ was calculated from the ratio of the total number of ice crystals larger than $5 \mu \mathrm{m}$ detected by the MetOne during the growth experiment $\left(\mathrm{IC}_{>5}\right)$ to the average of the total number of aerosol particles smaller than $5.0 \mu \mathrm{m}\left(\mathrm{APS}_{<5}\right)$ measured before and after each ice nucleation experiment.
Quality control of the CFDC measurements

Filtered and dried air was used for both the sheath and aerosol flows. An ULPA air filter preceded by a HEPA air filter removed $99.97 \%$ of the ambient aerosols larger than $0.1 \mu \mathrm{m}$. The air streams were dried down to a dew point of $-73^{\circ} \mathrm{C}$ with anhydrous calcium sulfate Drierite (W.A. Hammond Drierite Co.). To check for the presence of any ice particle artifacts, both blank and dry experiments were conducted. In a blank experiment, no aerosol particles are input into the chamber flow, but the chamber walls are coated with ice. In a dry experiment, aerosol particles are input into the chamber, but there is no ice coating on the chamber walls. Before running any blank experiment, we passed dried and filtered air into the CFDC for about $8 \mathrm{~h}$ to remove all particles that may have remained inside the system from the previous experiment.

We used the total aerosol particle number concentrations smaller than $5.0 \mu \mathrm{m}\left(\mathrm{APS}_{<5}\right)$ averaged before and after the ice nucleation experiments in the calculation of the detected percentage of ice activation because it was not possible to measure the input aerosol number concentrations during the actual ice nucleation experiment. However, this does not pose any difficulties due to the high reproducibility $( \pm 5 \%)$ of the input aerosol number concentration. Since we are unable to differentiate between aerosol and ice particles less than $5.0 \mu \mathrm{m}$ in diameter using the MetOne particle counter at the exit of the CFDC, we assume that all particles greater than $5.0 \mu \mathrm{m}$ at the bottom of the CFDC are ice crystals. Hence, we are unable to report a total ice nucleation rate, but rather report the ice nucleation percentage based on the ratio of ice crystals that grew to sizes larger than $5.0 \mu \mathrm{m}$ to the pre-nucleation particle concentration.

To rule out the possibility of hygroscopic growth by the aerosol particles within the CFDC, it was checked whether montmorillonite adsorbed enough water vapor to grow larger than $5.0 \mu \mathrm{m}$. The test was done by setting the temperature of both ice-covered walls of the chamber to $-2^{\circ} \mathrm{C}$. The relatively warm temperature of $-2^{\circ} \mathrm{C}$ was chosen in order to get very close to water saturation conditions ( $98.1 \%$ relative humidity with respect to water, $\mathrm{RHw}$ ) in the chamber. The detected ice crystal fraction $\left(\mathrm{IC}_{>5} / \mathrm{APS}_{<5}\right)$ was only $0.04 \%$ at the outlet of the chamber, which is within the noise level as determined by the blank as well as the dry experiments. We did hygroscopic growth experiments for trace-gas-exposed montmorillonite dust aerosol particles as well. The results showed that there were no differences in detected fraction of ice nuclei (on average about $0.038 \%$ ) between trace-gas-exposed and non-exposed montmorillonite, i.e., there was no hygroscopic growth of dust particles. Moreover, we also carried out ice nucleation experiments using water vapor instead of trace gases to age the montmorillonite dust aerosols. The results indicated that water vapor has no significant effect on the ice nucleation 
Table 1 Experimental RHw and corresponding RHi in percentage for unexposed montmorillonite and trace-gas-exposed montmorillonite at different temperatures

\begin{tabular}{lcc}
\hline Temperature $\left({ }^{\circ} \mathrm{C}\right)$ & \multicolumn{2}{l}{ Corresponding RHi (\%) } \\
\cline { 2 - 3 } & \multicolumn{2}{l}{ For } \\
\cline { 2 - 3 } & $100 \%$ RHw & $90 \%$ RHw \\
\hline-10 & 110 & $100.1^{\mathrm{a}}$ \\
-15 & 116 & 104 \\
-20 & 122 & 110 \\
-25 & 128 & 115 \\
-30 & 136 & 121 \\
-35 & 143 & 127 \\
-40 & 148 & 133 \\
\hline
\end{tabular}

The calculations for the saturation pressures are given in Salam et al. (2007)

${ }^{\text {a }}$ Actually, temperature was $-10.2^{\circ} \mathrm{C}$ and the $\mathrm{SSw}$ was $90.6 \%$

ability of the montmorillonite dust aerosol particles. We also ran ice nucleation experiments after degassing of the trace gases from montmorillonite dust surfaces. Trace-gasexposed montmorillonite mineral dust particles were degassed at room temperature under a vacuum pressure of $1.3 \times 10^{-4}$ atmospheres. About $2.0 \mathrm{~g}$ of gas-exposed montmorillonite dust particles were placed in an aluminum container which was placed into a vacuum jar and maintained at vacuum for about $24 \mathrm{~h}$. The degassed montmorillonite was used for ice nucleation experiments. The results indicate that degassing has no effect on the ice nucleation of ammonia-, sulfur dioxide-, and ozoneexposed montmorillonite particles.

\section{Results and discussion}

Ice nucleation of ammonia-exposed montmorillonite

Ice nucleation experiments of montmorillonite mineral dust particles with and without ammonia exposure were carried out at temperatures between $-10^{\circ} \mathrm{C}$ and $-40^{\circ} \mathrm{C}$ at $90 \%$ RHws. The corresponding relative humidity with respect to ice (RHi) is given in Table 1. The same temperature and humidity conditions were used for the other trace gas experiments described below. A previous study with $100 \%$ pure and $25 \mathrm{ppm}$ ammonia-exposed montmorillonite showed that ammonia gas enhanced the ice nucleation efficiency of the montmorillonite dust aerosols by a factor of 2 to 8 as compared to unexposed montmorillonite (Salam et al. 2007). The $25 \mathrm{ppm}$ ammonia concentration used in Salam et al. (2007) was about 3,000 times higher than polluted atmospheric ammonia concentrations (Godish 2003). In the current study, a more realistic atmospheric concentration of ammonia gas of 100 ppt was used to observe the impact on the ice nucleation of the ammoniaexposed montmorillonite. Figure 2 shows the detected fraction of ice nuclei versus temperature of the unexposed montmorillonite, $100 \%$ pure ammonia-exposed montmorillonite, and $100 \mathrm{ppt}$ ammonia-exposed montmorillonite at $90 \%$ RHw. The ammonia gas aging times are $2.5 \mathrm{~h}$ for $100 \%$ pure ammonia and $70 \mathrm{~h}$ for $100 \mathrm{ppt}$ ammonia for all experiments. These exposure times were chosen because the ice nucleation efficiency of $100 \%$ pure ammonia-gasaged montmorillonite attains saturation within $2 \mathrm{~h}$, and $25 \mathrm{ppm}$ ammonia reached saturation within $18 \mathrm{~h}$ (Salam et al. 2007). An exposure time of $70 \mathrm{~h}$ represents an average lifetime of dust particles in the atmosphere (Textor et al. 2006). The efficiency of montmorillonite dust particles to act as ice nuclei at $90 \% \mathrm{RHw}$ increased two times at temperatures from $-30^{\circ} \mathrm{C}$ to $-20^{\circ} \mathrm{C}$, respectively, due to the modification of the montmorillonite dust surface with $100 \mathrm{ppt}$ ammonia gas after aging for about $70 \mathrm{~h}$. This is the first experimental evidence for the enhancement of the montmorillonite ice nucleation efficiency due to the modification of the dust surface with ammonia at typical polluted atmospheric concentrations. However, anthropogenic enhancement of ammonia concentrations in the atmosphere may alter the cloud properties due to their ability to change ice nucleation efficiency of mineral dust aerosols.

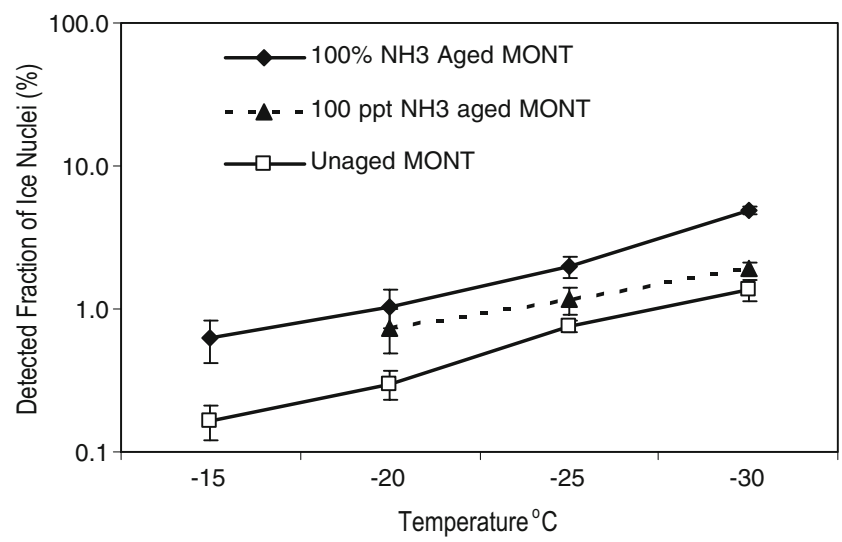

Fig. 2 Percentage of detected fraction of ice nuclei versus temperature of unaged montmorillonite (MONT), $100 \mathrm{ppt}$ and 100\% pure ammonia-exposed montmorillonite mineral dust aerosols, respectively, at $90 \%$ relative humidity with respect to water $[R H w$; the corresponding relative humidity with respect to ice $(\mathrm{RHi})$ is given in Table 1]. The exposure time was $2.5 \mathrm{~h}$ for $100 \%$ pure ammonia gas and $70 \mathrm{~h}$ for $100 \mathrm{ppt}$ ammonia gas exposure on the montmorillonite mineral dust surface. The percentage of activated ice nuclei $\left(\mathrm{IC}_{>5} /\right.$ $\mathrm{APS}_{<5}$ ) was calculated from the ratio of the total number of ice crystals larger than $5.0 \mu \mathrm{m}\left(\mathrm{IC}_{>5}\right)$ to the average of the total number of aerosol particles smaller than $5.0 \mu \mathrm{m}\left(\mathrm{APS}_{<5}\right)$ before and after the ice nucleation experiments. The vertical bars refer to the standard deviation of the 15 measurements conducted at each temperature 


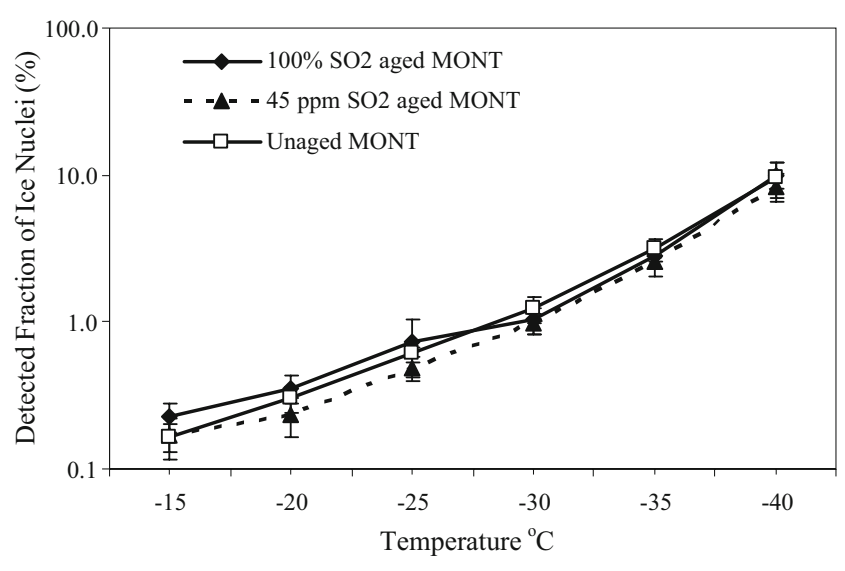

Fig. 3 Percentage of detected fraction of ice nuclei (as defined in Fig. 2) versus temperature of unaged montmorillonite, $100 \%$ pure and $45 \mathrm{ppm}$ sulfur dioxide gas-exposed montmorillonite at $90 \%$ relative humidity with respect to water $[R H w$; the corresponding relative humidity with respect to ice $(\mathrm{RHi})$ is given in Table 1]. The exposure time for these experiments was $2.5 \mathrm{~h}$ for $100 \%$ pure sulfur dioxide and $70 \mathrm{~h}$ for $45 \mathrm{ppm}$ sulfur dioxide. The vertical bars refer to the standard deviation of the 15 measurements conducted at each temperature

Ice nucleation of sulfur-dioxide-exposed montmorillonite

The influence of sulfur dioxide on the ice nucleation of montmorillonite mineral dust aerosols was investigated at two different concentrations $\left(100 \%\right.$ pure and $45 \mathrm{ppm} \mathrm{SO}_{2}$ in $\mathrm{N}_{2}$ gas medium). The detected fraction of ice nuclei (\%) versus temperature of sulfur-dioxide-exposed montmorillonite at $90 \% \mathrm{RHw}$ are shown in Fig. 3. The gas exposure times to montmorillonite are $2.5 \mathrm{~h}$ for $100 \%$ pure $\mathrm{SO}_{2}$ and $70 \mathrm{~h}$ for $45 \mathrm{ppm} \mathrm{SO}_{2}$. The variation of the ice nucleation activity of sulfur-dioxide-aged montmorillonite with exposure times shows that sulfur dioxide gas exposure times have no effect on the montmorillonite ice nucleation efficiency. Note that the sulfur dioxide exposure time (as well as that of ozone as discussed below) is the same as for ammonia gas to maintain uniformity among the different gases. The detected fraction of ice nuclei increases with decreasing temperature for both $100 \%$ pure and $45 \mathrm{ppm}$ $\mathrm{SO}_{2}$-exposed montmorillonite. The ice nucleation activities of unaged montmorillonite and $\mathrm{SO}_{2}$-exposed montmorillonite were observed at much warmer temperatures (between $-15^{\circ} \mathrm{C}$ and $-20^{\circ} \mathrm{C}$ ) than homogeneous freezing. There is no significant difference in ice nucleation efficiency between unaged montmorillonite, $100 \%$ pure $\mathrm{SO}_{2}$-aged montmorillonite, and $45 \mathrm{ppm} \mathrm{SO}_{2}$-aged montmorillonite under the current experimental conditions.

Atmospheric sulfur dioxide $\left(\mathrm{SO}_{2}\right)$ converted to sulfuric acid $\left(\mathrm{H}_{2} \mathrm{SO}_{4}\right)$ through oxidation process (Usher et al. 2003; Umann et al. 2005). Thus, both $\mathrm{SO}_{2}$ and $\mathrm{H}_{2} \mathrm{SO}_{4}$ increase as a result of anthropogenic emissions of sulfur dioxide. Evidence shows that sulfuric acid coating on dusts particles does not change the ice nucleation ability of pure dust aerosols (Knopf and Koop 2006). We reached the same conclusion for $\mathrm{SO}_{2}$ such that it has no noticeable impact on the heterogeneous ice nucleation of montmorillonite dust aerosols.

Ice nucleation of ozone-exposed montmorillonite

Montmorillonite mineral dust aerosol particles were exposed to ozone gas at a polluted urban atmospheric concentration of $200 \mathrm{ppb}$. The exposure time for ozone to the montmorillonite mineral dust particles was $70 \mathrm{~h}$. The ozone exposure times had no effect on the ice nucleation efficiency of the aged montmorillonite. Figure 4 shows the detected fraction of ice nuclei in percentage (\%) versus temperature at $90 \% \mathrm{RHw}$ after exposure to ozone gas. Ozone-exposed montmorillonite acts as efficient ice nuclei, with the ice nucleation efficiency increasing with decreasing temperature. There is no significant difference in the ice nucleation efficiency between ozone-exposed and unexposed montmorillonite between the temperatures of $-15^{\circ} \mathrm{C}$ and $-40^{\circ} \mathrm{C}$. Enhancement of the ozone concentrations in the atmosphere due to anthropogenic activities does not change the ice nucleation efficiency of the montmorillonite mineral dust aerosol particles either.

Interpretation and atmospheric implications of the results

Fourier transform infrared measurements revealed that ammonia gas chemically adsorbed on the montmorillonite surface (Salam et al. 2007). Adsorption may take place by hydrogen bonding, exchanging cations, or the formation of

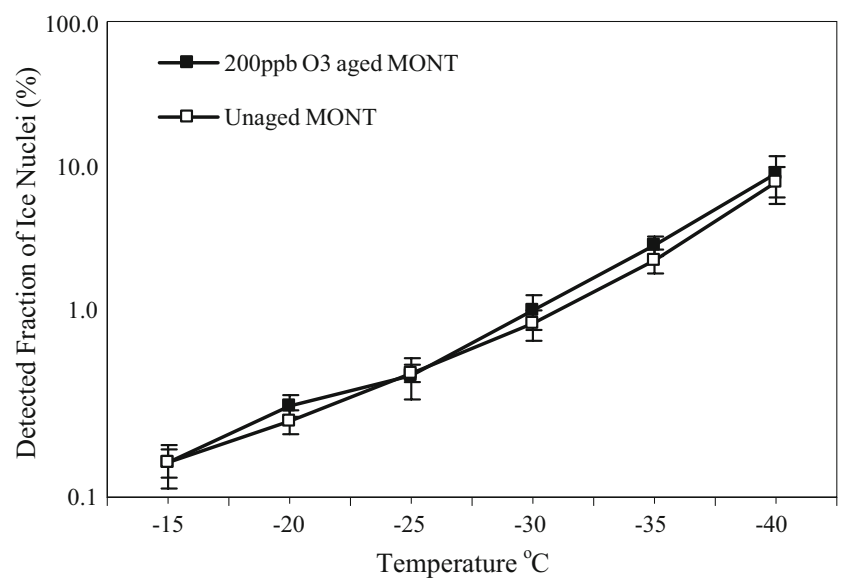

Fig. 4 Percentage of detected fraction of ice nuclei (as defined in Fig. 2) versus temperature for unaged montmorillonite and $200 \mathrm{ppb}$ ozone-exposed montmorillonite mineral dust aerosols at $90 \%$ relative humidity with respect to water $[R H w$; the corresponding relative humidity with respect to ice $(R H i)$ is given in Table 1]. The ozone gas exposure time on montmorillonite dust surface was $70 \mathrm{~h}$. The vertical bars which are barely visible are the error bars equal to the standard deviation of the 15 measurements conducted at each temperature 
ammonium ions with the functional groups on the surface of the montmorillonite (e.g., Russell 1965; Dontsova et al. 2005). The adsorption of ammonia gas on the montmorillonite surface increases the possibility of liquid water uptake through hydrogen bonding, exchanging cations, or the formation of ammonium salts. That enhances the possibility of ammonia-exposed montmorillonite ice nucleation efficiency in the deposition nucleation mode. This may explain how the ice nucleation efficiency of ammoniagas-exposed montmorillonite mineral dust particles is enhanced.

On the other hand, there is no significant effect in the ice nucleation efficiency of montmorillonite after exposure to sulfur dioxide or ozone gases. One possible reason may be that they do not undergo any chemical interactions with montmorillonite dust aerosols. The literature suggests that there is very little interaction between mineral dusts and sulfur dioxide (Umann et al. 2005; Usher et al. 2003). Actually, different correlations (positive, negative, and no correlation) were detected between mineral dust and sulfur dioxide gas (Umann et al. 2005). In the case of ammoniaaged montmorillonite, the hydrogen atoms of ammonia interact with oxygen atoms of either the hydroxide $(-\mathrm{OH})$ or silicates $\left(\mathrm{Si}_{3} \mathrm{O}_{4}{ }^{2-}\right)$ on the surface of montmorillonite. However, sulfur dioxide and ozone both have oxygen atoms that do not interact or do not have strong attraction towards silicates or hydroxide groups on the surface of montmorillonite dusts. This may explain why sulfurdioxide- and ozone-exposed montmorillonite do not exhibit an enhanced attraction towards the water vapor when they come into contact in the CFDC chamber flow and therefore be a factor in the lack of observed enhanced ice nucleation.

The potential role of the increasing concentrations of atmospheric trace gases, sulfur dioxide, and ozone due to anthropogenic activities do not have a significant effect on the ice nucleation efficiency of mineral dust aerosols, suggesting that these two gases have no impact on the change of the cloud properties, whereas increasing concentrations of ammonia gas have the ability to enhance the ice nucleation efficiency of montmorillonite mineral dust aerosols, which may subsequently change the cloud properties.

\section{Conclusion}

The effect of sulfur dioxide, ozone, and ammonia on the ice nucleating ability of montmorillonite mineral dust aerosol particles in deposition mode was studied for different temperature and saturation conditions with the Dalhousie University Continuous Flow Diffusion Chamber. Pure and polluted atmospheric concentrations of the trace gases were used for the aging of montmorillonite mineral dust aerosols. The sulfur dioxide-, ozone-, and ammonia-exposed mont- morillonite act as efficient ice nuclei at the warmer lower tropospheric temperatures of $-15^{\circ} \mathrm{C}$ to $-40^{\circ} \mathrm{C}$. Sulfur dioxide and ozone exposure do not significantly enhance nor inhibit the ice nucleation ability of montmorillonite mineral dust particles under the current experimental conditions. Ammonia gas exposure enhanced the ice nucleation efficiency of montmorillonite mineral dust by a factor of 2 at the typical concentrations found in polluted environments. Our study suggests that increasing levels of anthropogenic sulfur dioxide and ozone do not have a significant effect on the ice nucleation of montmorillonite mineral dust and have no effect on the change of the clouds properties, whereas increasing concentrations of ammonia gas have the ability to enhance the ice nucleation efficiency of montmorillonite mineral dust aerosol particles, which may subsequently change the cloud properties.

Acknowledgments We are grateful for the support from the Canadian Foundation for Climate and Atmospheric Sciences (CFCAS) and the National Science and Engineering Research Council (NSERC) of Canada. We thank Brian Crenna for his excellent work in constructing and testing the CFDC. We also acknowledge Kevin Borgel and Andy George for their technical help.

Open Access This article is distributed under the terms of the Creative Commons Attribution Noncommercial License which permits any noncommercial use, distribution, and reproduction in any medium, provided the original author(s) and source are credited.

\section{References}

Andreae MO, Charlson RJ, Bruynseels F, Storms H, Vangrieken R, Maenhaut W (1986) Internal mixture of sea salt, silicates, and excess sulfate in marine aerosols. Science 232:1620-1623 doi:10.1126/science. 232.4758 .1620

Archuleta CM, DeMott PJ, Kreidenweis SM (2005) Ice nucleation by surrogates for atmospheric mineral dust and mineral dust/sulfate particles at cirrus temperature. Atmos Chem Phys 5:2617-2634

Birstein S (1957) Studies on the effect of certain chemicals on the inhibition on nucleation. In: Weickmann H, Smith W (eds) Artificial stimulation on rain. Pergamon, New York, p 376

Birstein S (1960) Studies on the effect on chemisorbed impurities on heterogeneous nucleation. Am Geophys Union Monogr 5:247

DeMott PJ, Sassen K, Poellot MR, Baumgardner D, Rogers DC, Brooks SD, Prenni AJ, Kreidenweis SM (2003) African dust aerosols as atmospheric ice nuclei. Geophys Res Lett 30 (14):1732 doi:10.1029/2003GL017410

Diehl K, Simmel M, Wurzler S (2006) Numerical sensitivity studies on the impact of aerosol properties and drop freezing modes on the glaciation, microphysics, and dynamics of clouds. J Geophys Res 111:D07202 doi:10.1029/2005JD005884

Dontsova KM, Norton LD, Johnston CT (2005) Calcium and magnesium effects on ammonia adsorption by soil clays. Soil Sci Soc Am J 69:1225-1232 doi:10.2136/sssaj2004.0335

Field PR, Möhler O, Connolly P, Krämer M, Cotton R, Heymsfield AJ, Saathoff H, Schnaiter M (2006) Some ice nucleation characteristics of Asian and Saharan desert dust. Atmos Chem Phys 6:2991-3006 
Forster P, Ramaswamy V, Artaxo P, Berntsen T, Betts R, Fahey D, Haywood J, Lean J, Lowe D, Myhre G, Nganga J, Prinn R, Raga G, Schulz M, Van Dorland R (2007) Radiative forcing of climate change in climate change 2007: the physical science basis. In: Solomon S, Qin D, Manning M, Chen Z, Marquis M, Averyt KB, Tignor M, Miller H (eds) Contribution of Working Group I to the Fourth Assessment Report of the Intergovernmental Panel on Climate Change. Cambridge University Press, New York, pp 129-234

Godish T (2003) Air quality, 4th edn. Lewis Publishers, Boca Raton

Kanji ZA, Abbatt JPD (2006) Laboratory studies of ice formation via deposition mode nucleation onto mineral dust and $n$-hexane soot samples. J Geophys Res 111:D16204 doi:10.1029/2005JD006766

Knopf DA, Koop T (2006) Heterogeneous nucleation of ice on surrogates of mineral dust. J Geophys Res 111:D12201 doi:10.1029/2005JD006894

Kumai M (1961) Snow crystals and the identification of the nuclei in the Northern United States of America. J Meteorol 18:139-150

Kumai M, Francis KE (1962) Nuclei in snow and ice crystals on the Greenland ice cap under natural and artificially stimulated conditions. J Atmos Sci 19:474-481 doi:10.1175/1520-0469 (1962) $019<0474:$ NISAIC $>2.0 . C O ; 2$

Lohmann U, Feichter J (2005) Global indirect aerosol effects: a review. Atmos Chem Phys 5:715-737

Marple VA, Willeke K (1976) Impactor design. Atmos Environ 10:891-896 doi:10.1016/0004-6981(76)90144-X

McConnell JR, Aristarain AJ, Banta JR, Edwards PR, Simões JC (2007) 20th-Century doubling in dust archived in an Antarctic Peninsula ice core parallels climate change and desertification in South America. Proc Natl Acad Sci U S A 104(14):5743-5748 doi:10.1073/pnas.0607657104

Möhler O, Field PR, Connolly P, Benz S, Saathoff H, Schnaiter M, Wagner R, Cotton R, Krämer M, Mangold A, Heymsfield AJ (2006) Efficiency of the deposition mode ice nucleation on mineral dust particles. Atmos Chem Phys 6:3007-3021

Ogloza AA, Malhotra VM (1989) Dehydroxylation induced structural transformations in montmorillonite: an isothermal FTIR study. Phys Chem Miner 16:378-385 doi:10.1007/BF00199559

Penner D, Lagaly G (2001) Influence of anions on the theological properties of clay mineral dispersions. Appl Clay Sci 19:131-142 doi:10.1016/S0169-1317(01)00052-7

Peters TM, Leith D (2003) Concentration measurement and counting efficiency of the aerodynamic particle sizer 3321. J Aerosol Sci 34(5):627-634 doi:10.1016/S0021-8502(03)00030-2

Pruppacher HR, Klett JD (1997) Microphysics of clouds and precipitation. Kluwer, Norwell, MA

Ramanathan V, Crutzen PJ, Kiehl JT, Rosenfeld D (2001) Aerosols, climate, and the hydrological cycle. Science 294:2119-2124 doi:10.1126/science.1064034
Rogers RR, Yau MK (1989) A short course in cloud physics. Pergamon, Tarrytown, NY

Russell JD (1965) Infra-red study of the reactions of ammonia with montmorillonite and saponite. Trans Faraday Soc 61:2284-2294 doi:10.1039/tf9656102284

Salam A, Lohmann U, Crenna B, Lesins G, Klages P, Rogers D, Irani R, MacGillivray A, Coffin M (2006) Ice nucleation studies of mineral dust particles with a new continuous flow diffusion chamber. Aerosol Sci Tech 40(2):134-143 doi:10.1080/ 02786820500444853

Salam A, Lohmann U, Lesins G (2007) Ice nucleation of ammonia gas exposed montmorillonite mineral dust particles. Atmos Chem Phys 7:3923-3931

Sassen K (2005) Dusty ice clouds over Alaska. Nature 434:456 doi: $10.1038 / 434456 a$

Sassen K, DeMott PJ, Prospero JM, Poellot MR (2003) Saharan dust storms and indirect aerosol effects on clouds: CRYSTALFACE results. Geophys Res Lett 30(12):1633 doi:10.1029/ 2003GL017371

Textor C, Schulz M, Guibert S, Kinne S, Balkanski Y, Bauer S, Berntsen T, Berglen T, Boucher O, Chin M, Dentener F, Diehl T, Easter R, Feichter H, Fillmore D, Ghan S, Ginoux P, Gong S, Grini A, Hendricks J, Horowitz L, Huang P, Isaksen I, Iversen I, Kloster S, Koch D, Kirkevåg A, Kristjansson JE, Krol M, Lauer A, Lamarque JF, Liu X, Montanaro V, Myhre G, Penner J, Pitari G, Reddy S, Seland Ø, Stier P, Takemura T, Tie X (2006) Analysis and quantification of the diversities of aerosol life cycles within AeroCom. Atmos Chem Phys 6:1777-1813

Twomey S (1974) Pollution and planetary albedo. Atmos Environ 8 (12):1251-1256 doi:10.1016/0004-6981(74)90004-3

Ullerstam M, Johnson MS, Vogt R, Ljungstrom E (2003) DRIFTS and Knudsen cell study of the heterogeneous reactivity of $\mathrm{SO}_{2}$ and $\mathrm{NO}_{2}$ on mineral dust. Atmos Chem Phys 3:2043-2051

Umann B, Arnold F, Schaal C, Hanke M, Uecker J, Aufmhoff H, Balkanski Y, Van Dingenen R (2005) Interaction of mineral dust with gas phase nitric acid and sulfur dioxide during the MINATROC II field campaign: first estimate of the uptake coefficient $\gamma \mathrm{HNO}_{3}$ from atmospheric data. J Geophys Res 110: D22306 doi:10.1029/2005JD005906

Usher CR, Michel AE, Grassian VH (2003) Reactions on mineral dust. Chem Rev 103:4883-4939 doi:10.1021/cr020657y

Vali G (1985) Atmospheric ice nucleation - a review. J Rech Atmos 19:105-115

Zuberi B, Bertram AK, Cassa CA, Molina LT, Molina MJ (2002) Heterogeneous nucleation of ice in $\left(\mathrm{NH}_{4}\right)_{2} \mathrm{SO}_{4}-\mathrm{H}_{2} \mathrm{O}$ particles with mineral dust immersions. Geophys Res Lett 29(10):1504 doi:10.1029/2001GL014289 